\title{
LA EXPOSICIÓN DE MUSEO: UN LUGAR COMÚN ${ }^{1}$ \\ THE EXHIBITION OF THE MUSEUM: A COMMON PLACE
}

Por:

María del Mar López Rojas

Diseñadora Industrial

Universidad del Valle

delmarsito@gmail.com

Resumen: En el presente artículo se pretende dilucidar ciertos conceptos referentes a la evolución del tema museal, hasta su reto actual que sigue siendo una relación real y directa con la sociedad; considerando, específicamente, el papel que cumple la exposición de museo, como lugar común, medio de difusión y mediadora entre los tres entes que en ella confluyen: los visitantes con todas sus particularidades, los objetos que se exponen de acuerdo con algún criterio definido, usualmente en relación con las intenciones del tercer ente: la institución museal.

Palabras claves: Museo, Museología, Museografía, Exposición, Comunicación.

Abstract: This article is intended to clarify certain concepts concerning the evolution of the museum topic, to its current challenge which is still a real and direct relationship with society; considering specifically the role of the museum exhibition, as commonplace, broadcast medium and mediator among the three entities brought to it: visitors with all their peculiarities on one side; on the other one, items that are set according to some defined criteria, usually in relation to the intentions of the third entity, the museum as an institution.

Keywords: Museum, Museology, Museography, Exhibition, Communication. 


\section{Museo: evolución histórica del concepto}

El significado etimológico de la palabra Museo se remonta al latín musēum y éste del griego Movocíov (mouseion) que significaba "la casa de las musas" (Fernández, 1999, pág. 13). Sin embargo, su significado adquirido, es decir el concepto de Museo, ha venido transformándose de acuerdo con los hechos sociales que le afectan. Resulta pertinente entonces realizar un breve rastreo histórico que permita determinar la evolución y la transformación del concepto ${ }^{2}$.

De acuerdo con varios autores (Valdés Sagüés, 1999, pág. 29; Hernández Hernández, 1992, pág. 85) el origen del concepto de museo, tal como se entiende hoy, se encuentra determinado por dos factores fundamentales: el coleccionismo y la ilustración. Según Hernández estos hechos fueron fundamentales no sólo para el surgimiento de las instituciones, sino también para la determinación del carácter público o privado de las mismas, ya que los museos privados — en su mayoría americanos - se gestaron en las bases del coleccionismo de carácter privado, mientras que la gestación de los museos públicos europeos fue definida en gran medida por la ilustración, como se verá más adelante.

El coleccionismo se remonta a la aparición del hombre en la tierra cuando este optaba por recoger y guardar diferentes objetos de su entorno, que podían o no ser funcionales pero que, de algún modo, le significaban algo. En palabras de Luis Alonso Fernández "todas las sociedades humanas en todos los lugares y épocas han sentido la necesidad ritual y sacra de crear y conservar colecciones de objetos significativos, de artefactos excepcionales o muy representativos, con la finalidad esencial de construir una comunicación cultural" (Fernández, 1999, pág. 91). Sin embargo, durante la historia del coleccionismo esta actividad fue considerada, en principio, como una práctica privada: desde los primitivos humanos prehistóricos que recogían y guardaban objetos cargados de valor simbólico, hasta los faraones en Egipto que acumulaban en sus haberes valiosos objetos que eran frecuentemente enterrados junto con ellos. Fue únicamente hasta mediados del mundo clásico que las colecciones empezaron a adquirir un carácter colectivo con la aparición de las primeras calcotecas y pinacotecas griegas donde se albergaban y exhibían ofrendas a los dioses.

Posteriormente, durante la época helenística aparecieron otras características propias del coleccionismo actual: la valoración de los objetos por su creadores, el aprecio de la obra de arte como testimonio del pasado y el desarrollo de un mercado artístico fundamentado (Valdés Sagüés, 1999, pág. 29), lo cual amplió el acceso a las obras y lo objetos de colección. 
Más adelante, en Roma, estas características fueron esclareciendo una suerte de conciencia sobre la obra de arte como patrimonio público; si bien algunas riquezas obtenidas como botín de guerra iban a parar a la propiedad privada del vencedor, la mayoría eran donadas a templos o edificios destinados para su conservación (Valdés Sagüés, pág. 30).

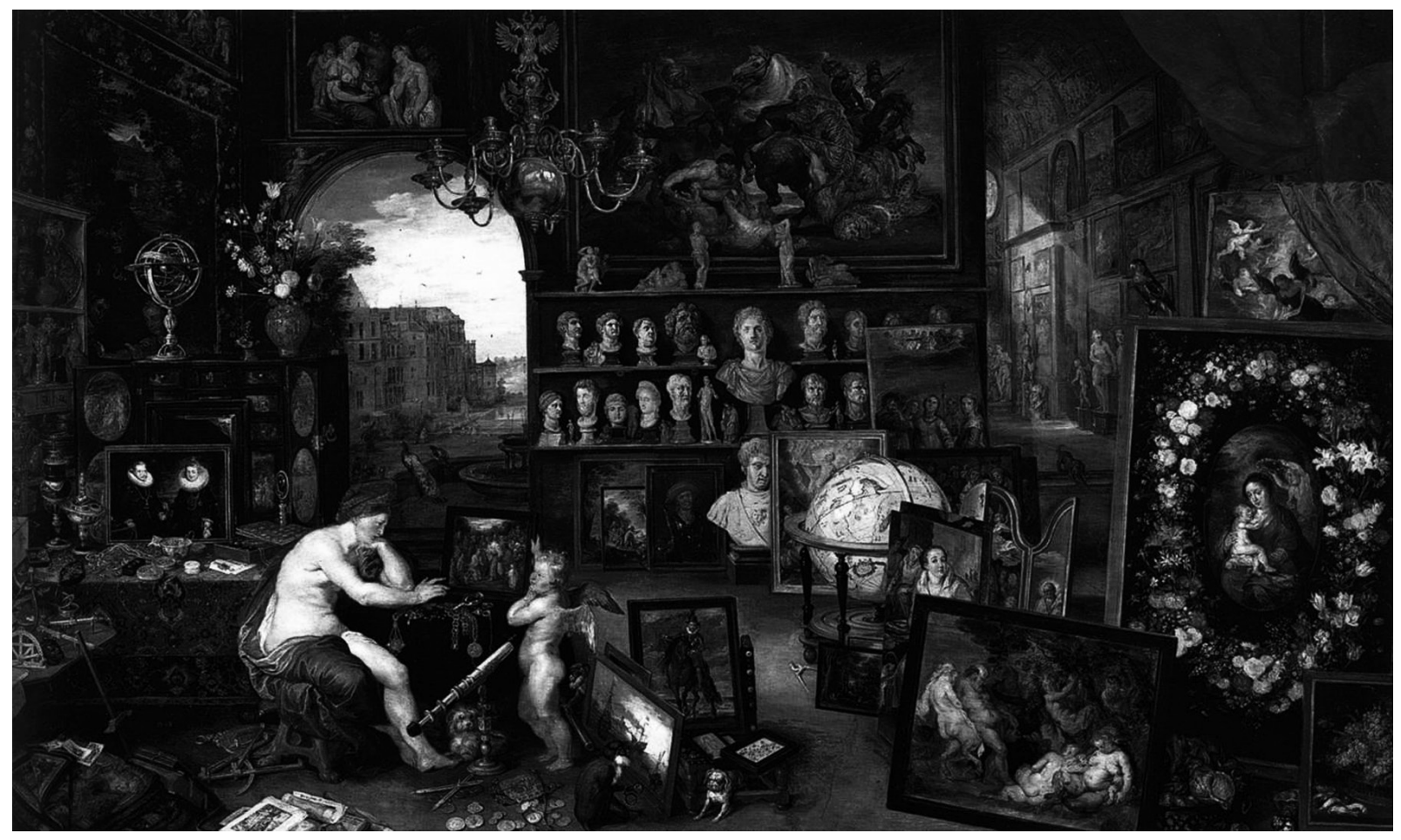

Figura I 1. "El Sentido de la Vista”, 1618 Óleo sobre Tabla.

Esta obra de Jan Brueghel con colaboración de Peter Paul Rubens, es una excelente representación de las "cámaras de maravillas" que demuestra el interés por el coleccionismo privado. Fuente: Web Gallery of Art.

La Edad Media supuso un cambio de paradigma. Después de la división del Imperio, en Occidente desaparecieron las costumbres romanas y las principales colecciones, que constaban de objetos artísticos valiosos, exóticos o raros, pasaron a pertenecer únicamente a la Iglesia y a los nobles, quienes para su almacenamiento construyeron las llamadas "cámaras del tesoro" que pronto se vieron transformadas en "cámaras de maravillas" o "gabinetes de curiosidades". Estas cámaras o gabinetes otorgaban a sus dueños tanto reconocimiento social — en el caso de los objetos artísticos y valiosos_-, como el poder sobre la ciencia — en el caso de los objetos exóticos y raros.

Durante el siglo XVI en los gabinetes de curiosidades se fue abandonando el antiguo interés en los objetos como tesoros y en cambio éstas fueron transformándose en lugar de encuentro para sabios e instruidos, quienes buscaban relacionar los objetos y tratar de explicarlos; recreando los contextos a los cuales pertenecían objetos y especímenes, estudiando sus características físicas y demás cualidades.

Este proceso de sistematización de las colecciones fue poco a poco delimitando las diferentes áreas saber científico. (Núñez, 2007, pág. 184). 
En el siglo XVII continuó la idea de superar el carácter privado del coleccionismo y fueron creados entonces museos de carácter público en Italia, Francia y Suiza (Valdés Sagüés, 1999, pág. 31). También durante este siglo un fenómeno importante tomó lugar en los museos, al separar los conceptos de arte y ciencia por considerarlos como "campos distintos de la actividad humana" (pág. 31).

La inquietud por la educación durante el Siglo de Las Luces, hizo que se abandonara por completo el carácter privado de las colecciones poniéndolas a disposición de la investigación y la enseñanza. Finalmente se considera La Revolución Francesa como hito en la historia de los museos, con la creación en 1791 del Museo de la Republica (actual Museo del Louvre). La importancia de este hecho radica no sólo en el carácter público del museo, sino que además llevaba consigo según Valdés, "la nacionalización del patrimonio histórico-artístico, la democratización de los bienes culturales, jurídicamente de naturaleza pública y la universalización de la educación”(Valdés Sagüés, 1999, pág. 32)

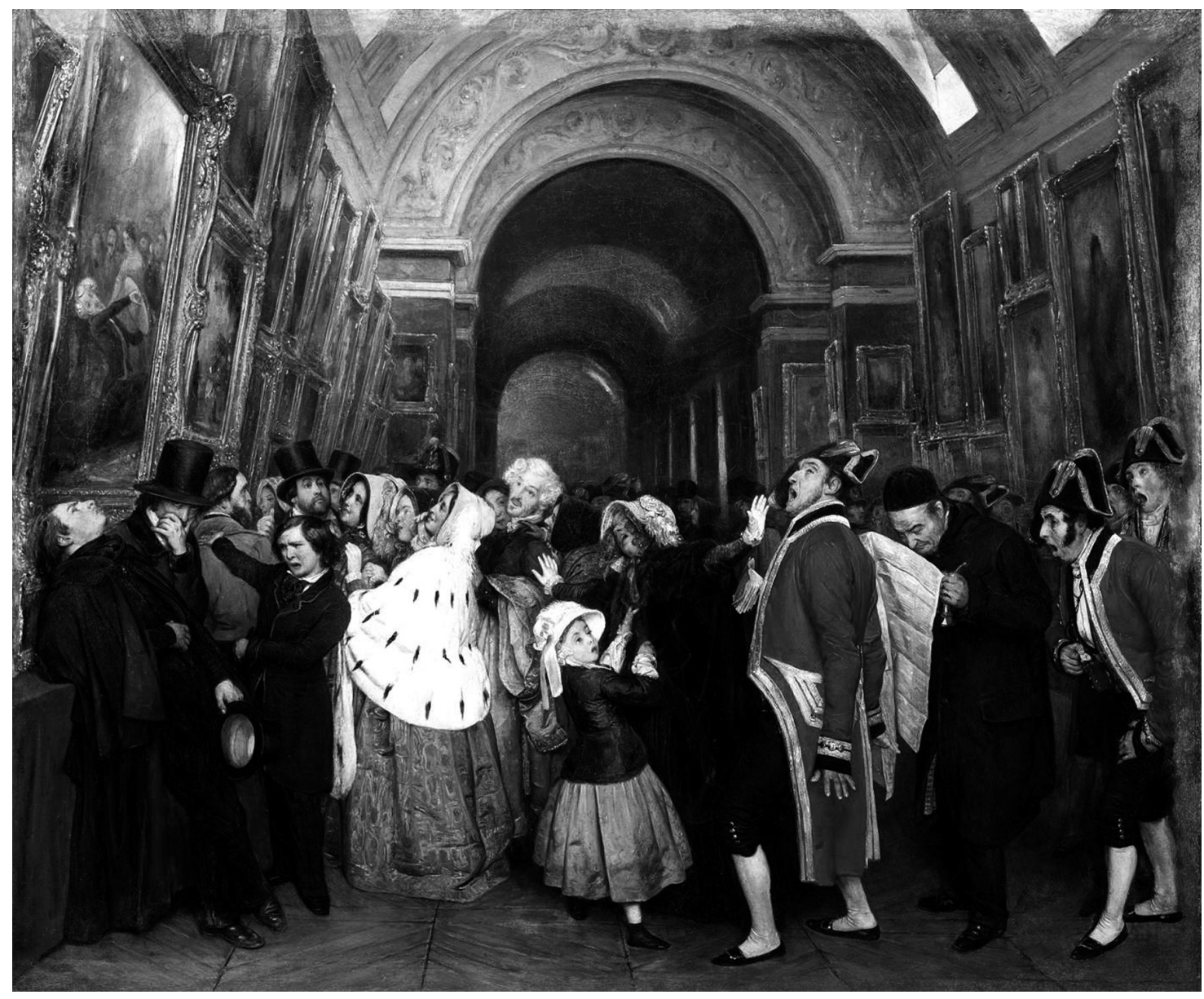

Figura I 2. François Auguste Biard, "Cuatro horas en el Salón (Cierre del Salón anual de pintura en la Gran Galería del Louvre)”. 1847, óleo sobre lienzo. Fuente: Europeana Portal. 
A partir del siglo XVIII y durante el siglo XIX los museos empezaron a convertirse en instituciones más complejas. Si bien en principio la función del museo se centraba en recoger y custodiar objetos, la dinámicas propias de la institución fueron complejizando sus funciones; en este sentido los objetos pasaron a representar información valiosa, lo cual despertó el interés científico en los mismos. Posteriormente la intención fue volcándose hacia la sociedad, buscando modos para que las colecciones se encontraran a su alcance.

Sin embargo a finales del siglo XIX y principio del XX, debido al presuroso afán por la conservación y la investigación, se primó nuevamente el objeto, rindiendo culto a la información que puede poseer. Los discursos científicos y curatoriales especializados se tomaron los museos del mundo dotándolos de un prestigio accesible para unos pocos. Las críticas al museo convertido en mausoleo, en un lugar elitista y lejano no se hicieron esperar y a mediados del siglo XX se empezaron a replantear los conceptos, tanto del museo en sí como de sus alcances, sus funciones y sus objetivos.

Las discusiones de principio del siglo XX en torno 'al deber ser del museo' fueron estructurándose a través de la conformación de instituciones como la Oficina Internacional de Museos, dependiente de la Sociedad de Naciones (1926-1935), sustituida por el Consejo Internacional de Museos (1946) — ICOM por sus siglas en inglés_organismo afiliado a la UNESCO y que regula hasta nuestros días, las normas profesionales, los estándares, los códigos de ética y algunas actividades de las instituciones museísticas a nivel mundial (International Council of Museums, 2010).

Después de diversas vicisitudes, el rol del museo siguió definiéndose en una lenta evolución hacia lo que, según varios autores, continúa siendo el reto: la apertura social (Valdés Sagüés, 1999, pág. 35; International Council of Museums, 2010, pág. 10).

\section{Museo, museología y museografía}

Con el deber ser haciéndose cada vez más complejo, fue pertinente determinar una acepción para el museo. En la XI Asamblea General del ICOM en Copenhague (1974) se puntualizó en los estatutos y se otorgó la siguiente definición:

«El museo es una institución permanente, sin finalidad lucrativa, al servicio de la sociedad y de su desarrollo, abierto al público, que adquiere, conserva, investiga, comunica y exhibe para fines de estudio, educación y de deleite, testimonios materiales del hombre y su entorno.»

XI Asamblea General del ICOM en Copenhague, 1974 (Fernández, 1999, pág. 67)

Con el mismo afán por encontrar las más adecuadas definiciones para las actividades relacionadas al museo, se empezaron a dilucidar dos campos de intervención que lo comparten como objeto de estudio: la museología y la museografía. La búsqueda tanto por una definición para cada una, como por el origen de las mismas ha dado pie a numerosos debates entre diversos profesionales ${ }^{3}$. 
Aun cuando estos conceptos aparecieron a mediados del siglo XVIII, el debate sobre el uso de la terminología, las características, los alcances y los objetivos tanto de una como de la otra continuó hasta bien entrado el siglo XX. Después de mucha reflexión, se abordó en 1970 una definición que esclareciera los conceptos y evitara confusiones terminológicas.

«La Museología es la ciencia del museo; que estudia la historia y razón de ser de los museos, su función en la sociedad, sus peculiares sistemas de investigación, educación y organización, relación que guarda con el medio ambiente físico y clasificación de los diferentes tipos de museos» Definición de ICOM News, 1970 (Fernández, 1999, pág.186)

«La Museografía es la técnica que expresa los conocimientos museológicos en el museo. Trata especialmente sobre la arquitectura y ordenamiento de las instalaciones científicas de los museos».

Definición de ICOM News, 1970 (Fernández, 1999, pág. 186)

Las definiciones propuestas por el ICOM en los años setenta del siglo XX constituyen un referente internacional en la actualidad, y reflejan el espíritu de lo que se llamó la revolución del museo que venía gestándose desde mediados de los sesentas, en contraposición a la herencia legada por el siglo anterior (Fernández, 1999).

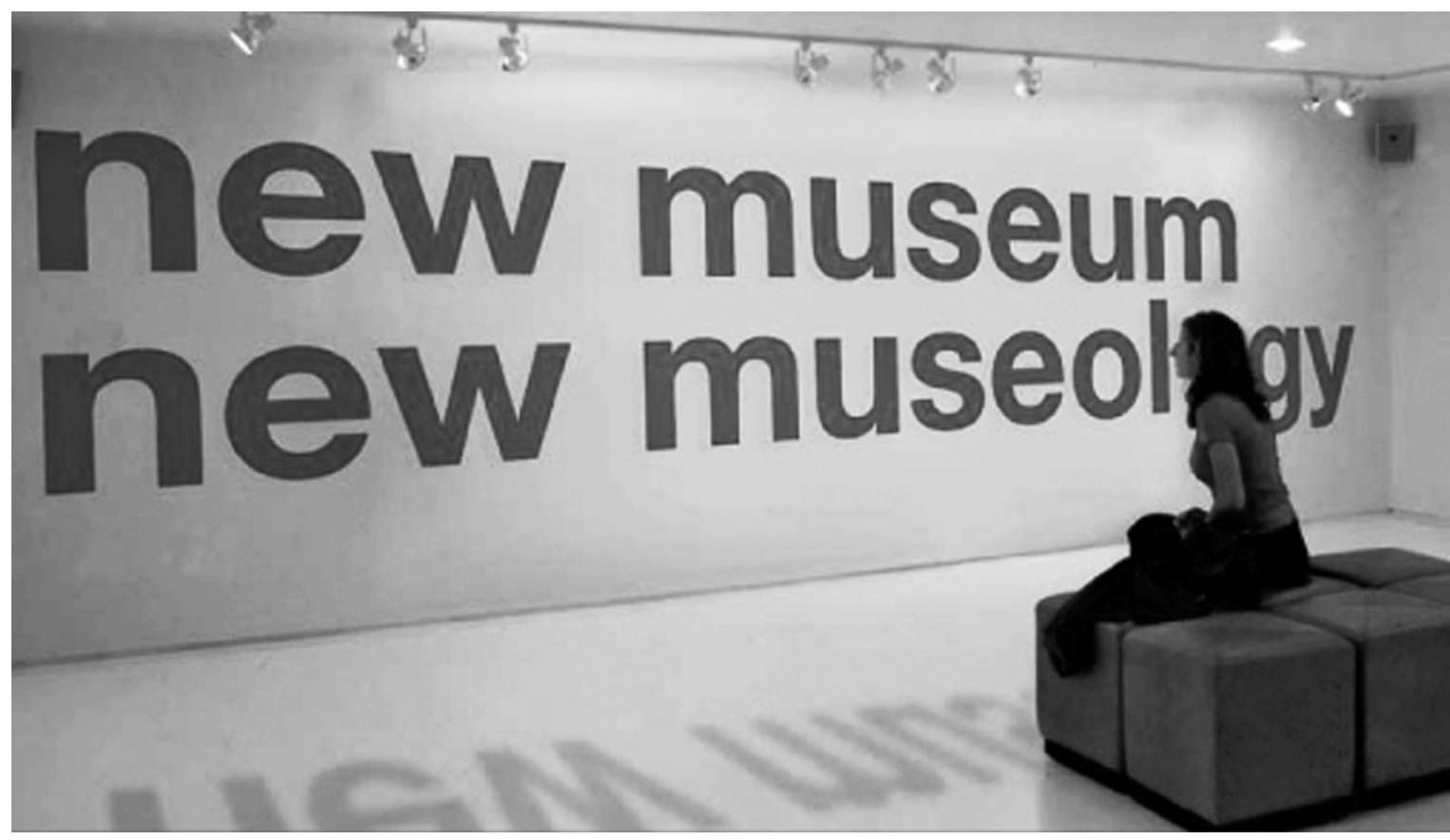

Figura I 3. "New Museum, New Museology", Simposio de Historia del Arte en Savannah College of Art and Design, 2008. Fuente: District the student voice of SCAD. 
Con la mirada puesta en la apertura social, los conceptos han ido actualizándose dando cabida a nuevas acepciones para cada uno de los términos. En la actualidad y según el Comité Internacional para la Museología - ICOFOM - existen tres acepciones reconocidas para el concepto de museografía y cuatro para el de museología. Las acepciones reconocidas en 2010 por el ICOFOM en el documento de Conceptos Claves de Museología, dan muestra de la creciente teorización sobre los temas referentes al museo y tratan de abarcar los diferentes postulados acatando sus contextos. También hacen imperativo el nuevo paradigma que orienta ambas actividades museales en relación con los individuos a los que los museos sirven y a quienes se deben ${ }^{4}$. Abandonando la concepción de institución estática, ensimismada y elitista, este nuevo paradigma ha ido obligando a los museos alrededor del mundo a transformar su proceder con el fin último de volcar sus actividades hacia la sociedad.

De acuerdo con los postulados de la denominada nueva museología, el museo pasa de ser un edificio, a ser un territorio, es decir una estructura descentralizada; de ser poseedor de una colección a la valoración de ésta como patrimonio - bien sea material o inmaterial_-;y del público a una comunidad (Fernández, 1999, pág. 95). En esta transformación, consideramos que el mayor cambio conceptual lo supone la revaloración de los objetos/colección como patrimonio que es inherente a una comunidad, entendida tanto como "un grupo social completo, pero a menor escala, cuyos miembros comparten actitudes, creencias y valores, [...] propósitos e intereses concretos que los unen"(De Carli, 2004) (por ejemplo, las comunidades indígenas); así como también los "grupos o sectores de la sociedad que comparten intereses, vocabulario especializado y desarrollan actividades conjuntas" (De Carli, 2004, pág. 20) (por ejemplo el público visitante en un museo, conformado por diversas comunidades: científica, escolar artística etc, y que además se constituye como comunidad en sí misma).

Desde esta perspectiva, los objetos adquieren sentido únicamente en función del significado que le es otorgado por el hombre, en un contexto específico. El nuevo museo, busca entonces, confrontar al hombre con la realidad que supone el significado de dicho patrimonio (De Carli, 2004, pág. 21), para tal fin, lo conserva, lo investiga y lo comunica.

\section{El museo y sus funciones: conservación, investigación y comunicación}

Las funciones del museo han estado directamente relacionadas con la definición otorgada por el ICOM en 1974, no obstante en 2007 esta acepción fue reajustada después de más de 30 años de vigencia.

«El museo es una institución permanente, sin fines de lucro, al servicio de

la sociedad y de su desarrollo, abierta al público que adquiere, conserva, estudia, expone y transmite el patrimonio material e inmaterial de la humanidad y de su medio ambiente con fines de educación y deleite »

International Council of Museums, 2010, pág. 52. 
En general, el cambio parece sutil. La actual definición incluye los conceptos de patrimonio material e inmaterial — lo cual resulta apenas lógico desde el nuevo paradigma museológico- - pero además en la versión en español, se hace una evidente distinción entre los antiguos términos que definían las funciones de investigación y comunicación, que son remplazados por los términos estudio y transmisión respectivamente ${ }^{5}$.

De acuerdo con lo expuesto en el documento de Conceptos Básicos sobre Museología, publicado por el ICOM en 2010, este ajuste terminológico se relaciona directamente con la realidad actual de los museos, donde la actividad investigadora ha sido relegada fuera de los mismos, hacia los laboratorios y universidades (pág. 52).

Por su parte, la adopción del término transmisión en vez de comunicación se debe, según el documento, a que la generalidad de la comunicación en el ámbito museal, se caracteriza por ser un proceso unidireccional (pág. 29). Sin embargo, al examinar el documento con mayor detalle, estas explicaciones sobre las variaciones conceptuales que supone el cambio terminológico en la definición, se contradicen con el desarrollo de la idea general que es abordada, desde el modelo de Preservación, Investigación y Comunicación (PRC por sus siglas en inglés) propuesto por académicos de la Reinwardt Academy ${ }^{6}$ a finales de la década de los ochenta (pág. 20).

Pareciera entonces que en la traducción al español, no existe aún una explicación concreta que justifique el cambio terminológico de esas funciones y por el contrario la ambigüedad presentada con relación a la diferencia o similitud entre los términos favorece, en este respecto, el uso de la antigua definición debido a que las cinco funciones del museo - tal cual se presentan en la definición del ICOM en 1974— se circunscriben terminológicamente dentro de las enunciaciones del modelo $P R C$, que a su vez sugiere ser el referente visible que cohesiona los muchos y diferentes términos usados en las definiciones de las funciones del museo.

El modelo PRC desarrollado por el museólogo Peter Van Mensh, profesor de Reinwardt Academy, constituyó un "nuevo paradigma” (Weil, 1992, pág. 74) sintetizando en tres funciones - preservación, investigación y comunicación - las cinco responsabilidades básicas del museo que habían sido definidas en 1970 por Joseph Veach Noble en el "Museum Manifesto": coleccionar, conservar, estudiar, interpretar y exhibir.

En el modelo PCR, la preservación relaciona las funciones de colección y conservación de Noble, considerando la primera como el primer paso en la construcción de una colección en función de un objetivo específico, en donde se considera la habilidad del museo para proveer el nivel de cuidado pertinente (lo cual podría asociarse a la conservación). El término resulta acertado, puesto que se separa de otras expresiones que puedan sugerir interpretaciones referentes a la colección como la aglomeración de objetos per se; característica fundamental de la antigua concepción del museo. Las funciones de adquisición y conservación definidas por el ICOM, así como las de restauración registro y documentación descritas por la antropóloga Georgina De Carli (2004, pág. 81), también son consideradas en el marco de la preservación como función básica del museo. 
La investigación, precisada por el ICOM en 2010 como el "estudio" del patrimonio material e inmaterial, se define tanto desde los testimonios referidos a la investigación del patrimonio, apoyándose principalmente en las colecciones — actividad museal clásica-; como también a las consideraciones museológicas, donde el museo en sí es el objeto de estudio y se reflexiona en torno a las técnicas, la ética y la crítica de lo museal, es decir, desde la museografía y la museología (2010, pág. 45).

Finalmente la comunicación o transmisión que se orienta hacia toda actividad que sirva para transmitir información a una audiencia incluye la función de exhibición-exposición propuestas por el ICOM (1974 y 2007), pero también actividades relacionadas con educación y relaciones públicas (De Carli, 2004, pág. 82; International Council of Museums, 2010, pág. 20).

El paradigma propuesto por el modelo PCR, fusiona las funciones de interpretación y exhibición de Nobles en una sola, determinada por Van Mensh como comunicación. En esta perspectiva, las funciones anteriores no se combinan, sino que se consideran intrínsecamente relacionadas por lo que resultan inseparables, lo cual pone de manifiesto que la función expositiva, como también las otras formas de transmisión en el museo, son moldeadas por las particularidades de aquellos que deciden lo que se quiere decir y como se dice (Weil, 1992), así como también de aquellos que reciben e interpretan, desde sus propias particularidades, lo que se les ha dicho.

La comunicación, según el PRC, comprende la transmisión y exhibición/exposición, definidas por el ICOM (1974 y 2007) e incluye actividades relacionadas con la educación y las relaciones públicas que buscan, entre otras cosas, proveer acceso, diseminar información, instruir, clarificar situaciones históricas o contemporáneas y sus relaciones, producir estándares, introducir y/o fortificar valores culturales, desarrollar habilidades, establecer y promover identidad social, etc. (Weil, 1992).

El modelo PRC constituye entonces un sistema en donde cada función puede analizarse como un proceso de entrada-transformación- salida. No obstante corre el riesgo de convertirse, según Van Mensh, en un sistema cerrado (De Carli, 2004, pág.79).

Las funciones del museo son planteadas por María del Carmen Valdés Sagüés en una relación más o menos similar. Parafraseando a la autora, la función conservadora del museo permite rastrear los testimonios del pasado a través de los objetos conservados, mientras que la investigación "ilumina" dichos objetos, los dota de significado, concibe nuevos campos del conocimiento y de cierta forma capacita al museo en pro de la difusión del nuevo conocimiento hacia la sociedad, a través de diferentes medios (1999, pág. 38).

En los dos apartados anteriores las funciones del museo se exponen en un aparente equilibrio, aun así existe y ha existido preeminencia de una función sobre otra. Bien sea por sus intereses, por sus posibilidades económicas o por requerimientos políticos, los museos tienden a 'especializarse' enfocándose en una o dos funciones, dando como resultado museos con énfasis diferentes independientemente de su tipología. Esta situación puede relacionarse con lo expuesto por Van Mensh sobre la aplicación del modelo PRC, que corre el riesgo de convertirse en un sistema cerrado y "autista", por lo cual se advierte la necesidad de generar estrategias que propicien la retroalimentación de las funciones en relación con la comunidad (DeCarli, 2004). 
Las estrategias planteadas con el fin favorecer la apertura de las funciones del museo son variadas. DeCarli propone una cuarta función en la triada del modelo PRC, denominada reactivación, que comprende prácticas que integren la comunidad al museo como "socia y aliada” (2004, pág. 83).

Por su parte, existe otra corriente (Nogales Basarrate, 2004; Olmos, 2002; Pérez Santos, 2000; García Blanco, 1999), que además de considerar la investigación dentro del museo como una de sus funciones básicas, la proponen también como el eje y la estrategia que permite la retroalimentación con la comunidad y propicia la apertura social. Desde esta perspectiva, la investigación se entiende como una actividad que permea y se desarrolla en todos los campos del museo, tanto los que se relacionan directamente con los objetos (adquisición, documentación, conservación), como también con los relacionados a los visitantes del museo, bien sean especialistas o no (difusión, educación, relaciones públicas etc.). Es precisamente en este último aspecto donde la investigación se valida como eje y estrategia al entenderse, según Olmos, como un privilegio social (2002, pág. 211), por cuanto el museo como institución investigadora, debe recordar que se debe a la sociedad que le ha privilegiado haciéndole partícipe de sus hallazgos como también de sus procesos.

Con tal objetivo, la función investigadora en los museos ha venido diversificándose. En una primera instancia, la investigación trata de descifrar las múltiples lecturas que un objetodocumento puede contener, para lo cual se identifican y describen, se categorizan y comparan para finalmente ser reinterpretados en función de una situación concreta (García Blanco, 1999, pág. 29). Después de este recorrido los objetos se encuentran dotados de significado en lo que podría denominarse como clave especializada; $\sin$ embargo, la investigación debe ir más allá para lograr acercar a la sociedad al museo y viceversa. Los objetos en clave especializada dicen aún muy poco para quienes no conocen la clave, en este sentido la investigación se convierte en la búsqueda y la exploración de nuevas formas de entender el patrimonio. Para esto en el museo se debe valorar tanto el estatuto especializado del objeto, como también las relaciones que puedan construirse en función de lo que se quiere transmitir acerca de ese objeto y por su puesto a quien se lo quiere transmitir.

\section{La exposición}

La exposición como el mero acto de "poner a la vista", ha sido desde siempre parte fundamental del museo. Sin embargo la concepción del papel que cumple dentro de un museo actual, ha venido complejizándose de la mano del museo y a la par de sus otras funciones, principalmente de la investigación. La exposición entonces, ha empezado a presentarse como algo más que la exhibición de objetos, en cambio busca comportarse como un vehículo a través del cual el museo se muestra con una intención definida.

En este nuevo devenir, los objetos en la exposición se encuentran cargados de significado que les ha sido otorgado gracias a su previa investigación; sin embargo y paradójicamente debido al hecho investigativo, los objetos adquieren un significado en función de la disciplina desde donde se les haya estudiado, por lo cual seguirán diciendo muy poco para aquellos que no disponen de las herramientas suficientes para descifrar el discurso especializado. De acuerdo con la museóloga Ángela García Blanco, la exposición entendida como el medio que se "interpone en la comunicación haciendo que se altere la forma natural de percibir e interpretar la realidad en beneficio de la percepción e interpretación prevista" (García Blanco, pág. 69), está llamada a resolver la situación planteada, es decir que la exposición constituida como medio de comunicación del hecho investigativo, debería interponerse mediando entre el saber especializado y quienes no cuentan con las herramientas de interpretación necesarias para comprender la clave especializada en que éste es presentado. 


\section{La exposición como medio de comunicación}

Los primeros desarrollos teóricos sobre el museo y la exposición equiparados a un medio de comunicación, fueron elaborados por el museólogo canadiense Duncan Cameron, en 1968 (Castellanos Pineda, 2008). Cameron señaló la similitud entre la estructura del museo y la de un medio de comunicación, considerando el primero aún más complejo puesto que es al mismo tiempo emisor, medio y receptor. Cameron se basa en el modelo de comunicación de Claude Elwood Shannon para desarrollar el primer esquema de comunicación aplicado al museo (Fig.I-4), que comprende tres elementos: el emisor que es el museo; el medio que equivale a los objetos del museo, definidos por el autor como "las cosas reales" y el visitante como receptor. Posteriormente añade la retroalimentación (feed back) como base de verificación de la concordancia entre el mensaje que se emite y el que se recibe (Castellanos Pineda, 2008, pág. 25).

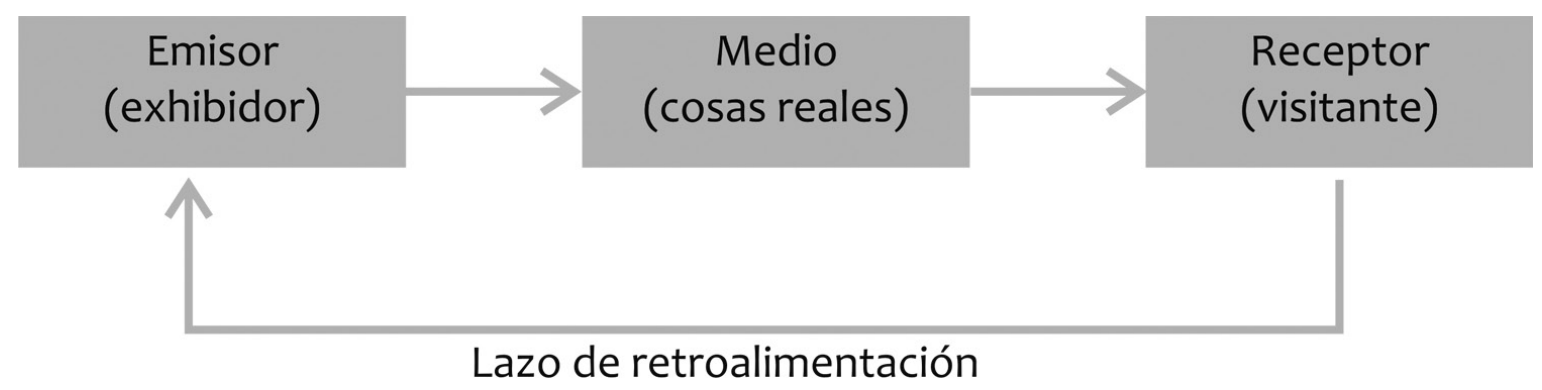

Figura I 4. Esquema de comunicación propuesto por Cameron integrando el feed-back. Fuente: Castellanos Pineda, 2008, pág. 25.

El modelo propuesto por Cameron constituyó un punto de partida que se ha desarrollado y ha evolucionado en la búsqueda de un nuevo sistema de comunicación que se interese más por la voz de los visitantes ante el mensaje que les es presentado.

Los museólogos estadounidenses Eugene I. Knez y GilbertWright se opusieron, en cierta medida, al modelo planteado por Cameron puesto que éste daba prelación al lenguaje visual, al presentar "las cosas reales" como único medio. Los autores consideraron de gran importancia la inclusión del lenguaje verbal como medio secundario, sobre todo en los museos de historia, ciencia y tecnología e historia natural, donde algunos conceptos requieren ser explicitados (Fig.I-5). 


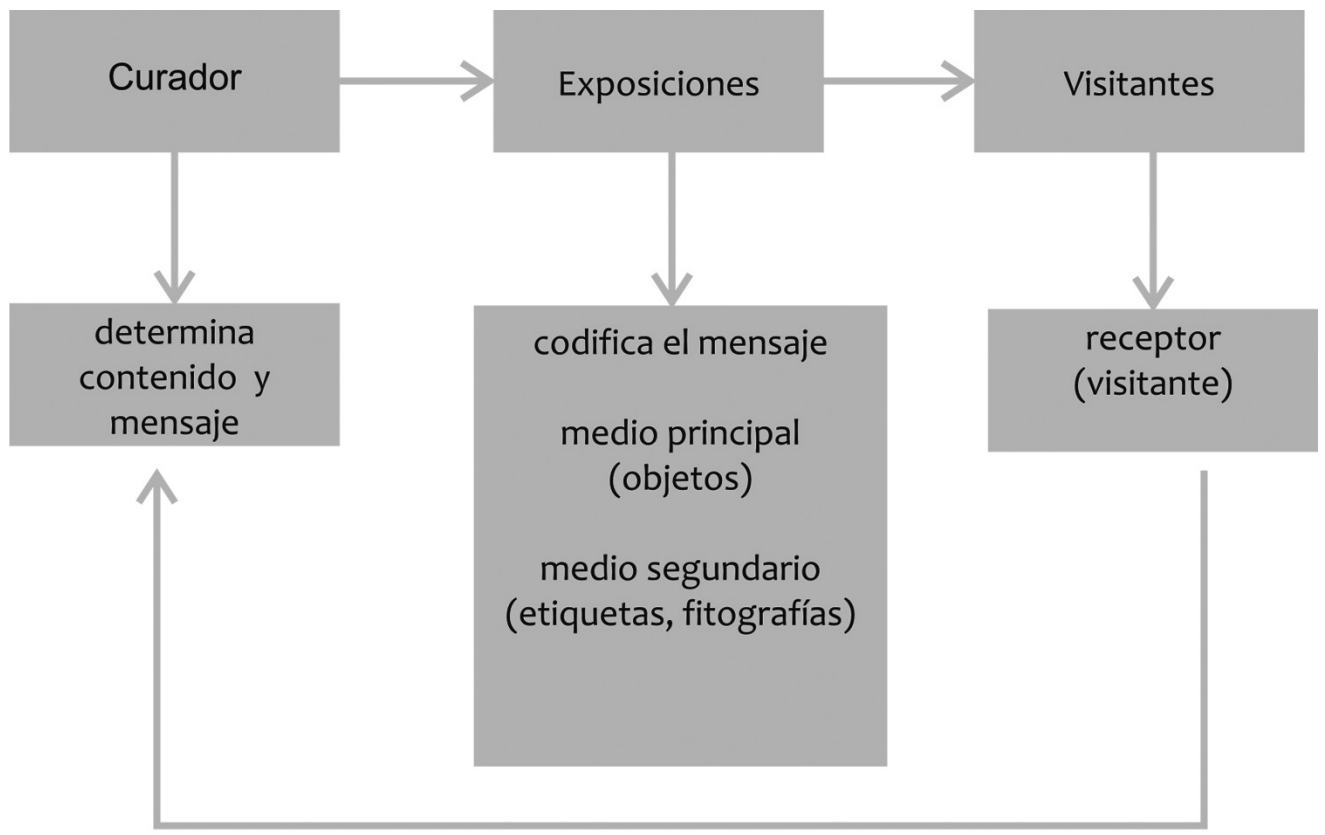

Mensajes contrastados con el feed-back

Figura I 5. Modelo de comunicación aplicado a los Museos de Ciencias según Knez y Wright Fuente: Hooper-Greenhill, 1998, pág. 37.

En este sentido, los autores consideraron que es el conservador/curador quien actúa como emisor, al ser el encargado de definir el mensaje que es vehiculizado en la exposición a través de los objetos como medio principal y de los textos, las fotografías, etiquetas y demás elementos gráficos como medio secundario, hasta los visitantes-receptores (Castellanos Pineda, 2008, pág. 27).

Desde la perspectiva del reto del museo actual, este modelo resulta interesante desde dos aspectos fundamentales: primero la presencia de curador como emisor que supone un trabajo de análisis y síntesis, previo a la exposición y que de cierta forma configura lo que se quiere decir y da un enfoque al mensaje. En segundo lugar la inclusión de un medio secundario que favorezca la interpretación de los objetos de las piezas de museo considerados como medio principal—-, pone de manifiesto la necesidad de proveer al visitante con herramientas que le permitan interpretar las piezas que ve, es decir hacer explícitos los conceptos, principalmente a través del lenguaje verbal. 
Por su parte, Robert Hodge y Wilfred D'Souza que desarrollaron el modelo propuesto por Cameron en un análisis semiótico de la Galería de Perth en 1976, (Castellanos Pineda, 2008) afirmaron sobre la comunicación en el museo que ésta incluye características de la comunicación natural, como también de la comunicación de los medios masivos definida como comunicación no natural. La comunicación natural o comunicación "cara a cara” abarca canales de soporte como el tono de voz, los gestos, el énfasis, etc. y además permite la rectificación, repetición y modificación del mensaje en cualquier momento en el que sea mal entendido o no se entienda del todo.

En el museo estas oportunidades de comunicación cara-cara se presentan a través de charlas, demostraciones, discusiones grupales, cursos, talleres y en el caso de la exposición, a través las visitas guiadas (Hooper-Greenhill, 1999). Lo anterior supone que las visitas libres al museo presentan características de comunicación no natural, donde el receptor (visitante) está presente, mientras que el emisor (equipo del museo) se encuentra ausente. En este sentido, según los autores, existen dos problemas usuales: cuando se dicen cosas que no son intencionadas (cosas que posiblemente el receptor no comprenda) o cuando no se dice o no se sabe cómo decir lo que se quiere (1999). Es decir que la complejidad de los discursos especializados requiere, en virtud de la exposición, un tratamiento especial.

Desde la perspectiva propuesta por Hodge y D'Souza, se enriquecieron los modelos de comunicación aplicados al museo, concretamente al museo de ciencias, utilizando como base el modelo Shannon y Weaver, el cual se propone un "sistema general de comunicación" (Fig.I-6) que se inicia en la fuente de información; el emisor es el encargado de transformar el mensaje en señal, capaz de ser transmitida por un canal. El canal es el medio a través del cual la señal es transmitida, desde el emisor hasta el receptor, y precisamente en el canal es donde puede incidir el ruido. Éste es definido como ciertos elementos externos o internos al proceso de comunicación, pero que no han sido intencionados por la fuente, por lo que pueden interrumpir o alterar la transmisión del mensaje. Finalmente, una vez recibida la señal por el receptor, éste la transforma de nuevo a mensaje que es transmitido al destinatario final. (Castellanos Pineda, 2008; Hooper-Greenhill, 1999).

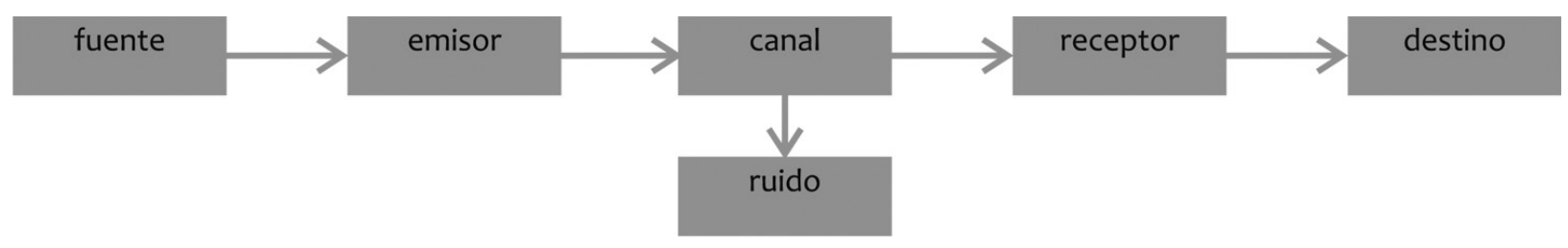

Figura I 6. Modelo de comunicación de Shannon y Weaver Fuente: Hooper-Greenhill, 1998, pág. 31. 
En el modelo de Shannon aplicado a los museos de ciencia (fig.7) la fuente de información está constituida por el conocimiento científico, la intención de lo que se quiere transmitir. El emisor es el equipo del museo, quien define qué y cómo decir lo que se quiere. El canal es la exposición compuesta de los diferentes elementos expositivos. El receptor lo integran los sentidos que advierten las señales y el destino final son los visitantes que reconstruyen el mensaje. El ruido se define como las interferencias entre la fuente y el destino (Castellanos Pineda, 2008) que en el caso de la exposición podrían ser de carácter formal o de contenido.

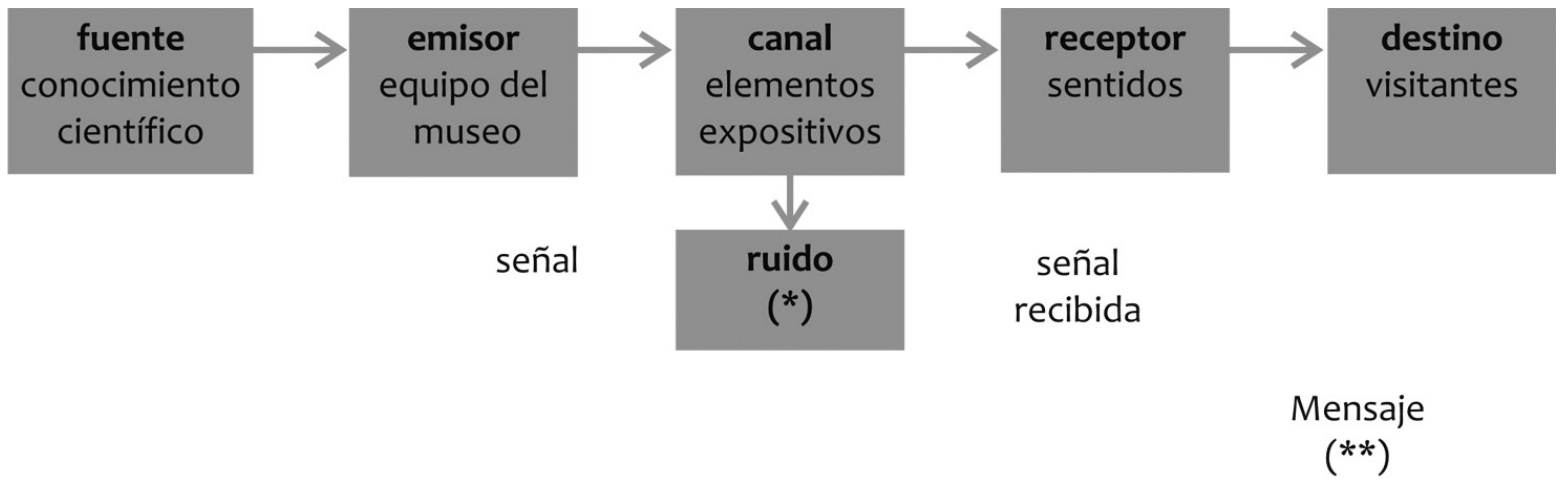

(*) Elementos que no permiten la total comprensión del mensaje. Por ejemplo, textos ilegibles o difíciles de entender, largos, con letra pequeña, exceso de público en sala, etc.

(**) El mensaje sería el contenido de la exposición o el estímulo.

Figura I 7. Modelo de Shannon y Weaver aplicado a los Museos de Ciencias. Fuente: Castellanos Pineda, 2008, pág. 30.

En este modelo, al igual que el planteado por Knez yWright, se evidencia el rol del emisor como aquel que define lo que se quiere decir, en función del conocimiento científico. Además dentro de la exposición como canal, se consideran diferentes elementos expositivos dentro de los cuales podrían incluirse tanto los objetos de la colección, como otros elementos del medio secundario propuesto por Knez y Wright.

Este modelo ha sido considerado limitado, debido a la "verticalidad" con que se propone el proceso de comunicación (Hooper-Greenhill, 1999), en donde no se visibiliza la participación de los visitantes — no existe feed-back, tal como se conoce- sin embargo, si se considera el ruido como una coyuntura para realizar evaluación de la exposición es posible encontrar aspectos relevantes en cuanto a la experiencia, la valoración y la opinión de los visitantes. 


\section{Las estrategias expositivas y los tipos de exposición: Museología de la Idea y Museología del Objeto}

La "museología de la idea" y la "museología del objeto" determinan dos maneras particulares de exponer, definidas por el estatuto dado al objeto. En "la museología del objeto" se fundamenta el estatuto dado al objeto por la ciencia positivista, mientras que en "la museología de la idea" se conceptualiza el objeto como portador de información, como signo significante, como soporte de significados referenciales (1999, pág. 60). García Blanco denomina estas exposiciones como "exposición de objetos" para el primer caso y "la exposición de objetos con ideas" para el segundo.

La diferencia fundamental entre una y otra es la existencia o ausencia de una línea argumental que cohesione a los objetos (García Blanco, 1999). Así la "exposición de objetos" se define por ser el espacio en el que ocurre el encuentro o el contacto con los objetos que, generalmente, han sido seleccionados en función de sus características individuales o por su pertenencia a un grupo taxonómico y son expuestos bajo una organización estructural simple de sucesión con base en un discurso que no es claro o que permanece oculto. En esta manera de exponer se privilegia entonces la valoración especializada de los objetos ya que, en cierta medida, se desconoce las particularidades del público que visita al museo al dar por sentado que éste será suficientemente capaz de entender los objetos y los conceptos expuestos sin que estos hayan sido explicitados.

En la "exposición de objetos con ideas" los objetos se agrupan en conjuntos portadores de conceptos, que van construyendo y reforzando conceptualmente, aquello que se quiere decir. En este caso, los objetos son relevantes únicamente en función y en coherencia con la idea que se quiere transmitir. Según Davallon ambas exposiciones cuentan con estrategias de comunicación, puesto que suponen la intensión previa de decir algo, sin embargo en el primer caso la exposición alcanza a informar sólo al experto, mientras que en el segundo, se tiene la intención de que la exposición abarque un espectro más amplio, comunicando un algo a los no expertos (García Blanco, 1999, pág.63).

Son precisamente las diferentes estrategias de comunicación, las que determinan diferentes tipos de exposición. En general los autores coinciden en las siguientes tipologías: las exposiciones cuyo fin es favorecer la contemplación, cuando no se tienen las herramientas suficientes para identificar el valor o el significado de lo expuesto son llamadas «contemplativas»o «estéticas» (García Blanco, 1999; Belcher, 1997). Tal es el caso de algunas exposiciones de arte o científicas, donde el objetivo es que el objeto se admire per se. Como ya se mencionó en esta exposición los objetos se valoran desde un conocimiento muy especializado.

Por la misma línea 'emocional', se encuentra las denominadas exposiciones «evocativas» y las «lúdicas» (García Blanco, 1999, pág.64) en este tipo de exposición, se pretende estimular en el visitante emociones, mediante la teatralización: el visitante entra a hacer parte de la representación. 
La exposición «informativa» (pág. 65) se relaciona también con las denominadas «pedagógica», «comunicativa» y «didáctica» (pág.65) ya que todas tienen una clara intención de transmitir información sobre los objetos, sin embargo en la exposición didáctica, tal como la define García Blanco existe una intensión por compartir recursos intelectuales, bien sea nuevos conocimientos o nuevas interpretaciones, por lo cual la información se ofrece ordenada y jerarquizada.. Además los objetos se explicitan a través de recursos adicionales que enseñan al visitante a pensar partiendo de las fuentes primarias, lo cual permite entre otras cosas, generar interpretaciones propias (García Blanco, pág. 65).
Finalmente, siguiendo a García Blanco consideramos la exposición como el medio que permite "traducir el discurso científico que da sentido a los objetos" (García Blanco, 1999, pág. 36). Para esto, la intencionalidad comunicativa del equipo productor procura que el mensaje se justifique en relación con los objetos que se exponen, y que éstos a su vez se conviertan intencionadamente en portadores de ideas; al mismo tiempo se reconoce al público como participante activo de la exposición, por lo cual se pone a disposición del visitante no experto, la información complementaria que oriente la interpretación. Esta posición alude, en cierta medida, al modelo de comunicación propuesto por Knenz y Wright y además se relaciona con la denominada "museología de la idea".

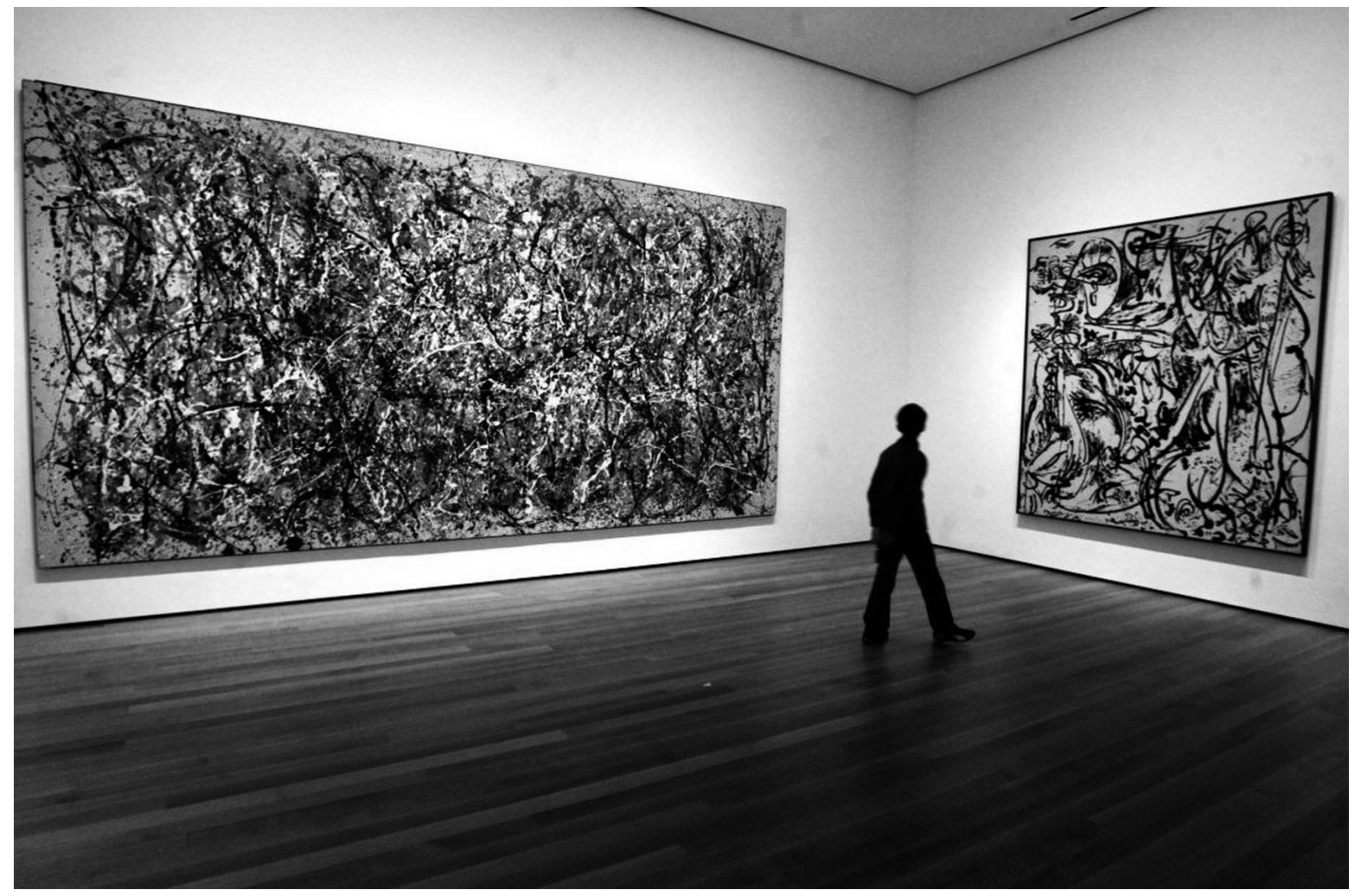

Figura I 8. Exposición de los 100 años del nacimiento de Jackson Pollock en el MoMa. Abril 22 de 2012. La actitud contemplativa se puede dar en una exposición con contenidos artísticos - como en la foto-o científicos cuando no existen las herramientas suficientes para que los visitantes no - expertos entender el valor o el significado de lo que ven (García Blanco; 1999). Fuente: Associated Press. 


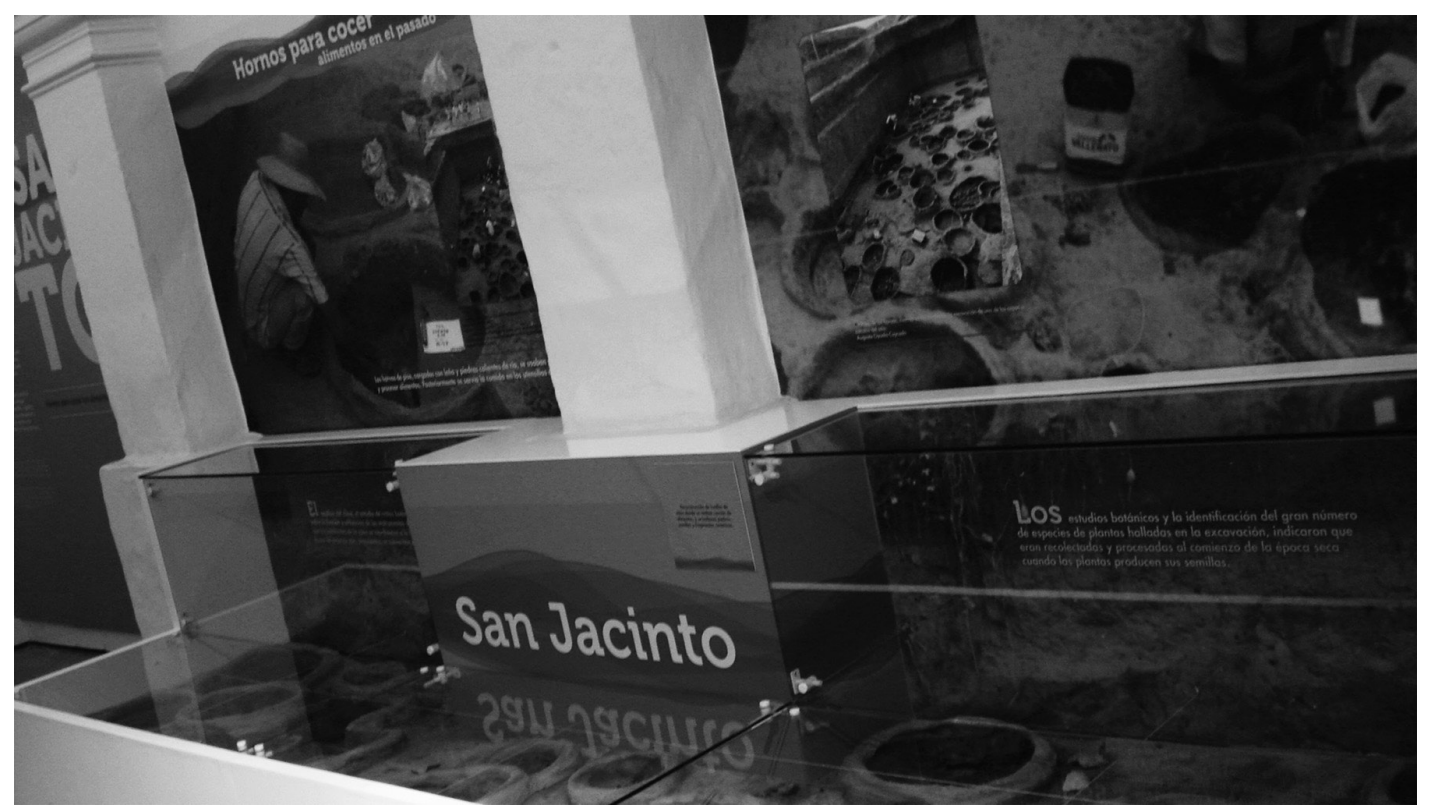

Figura I 9. Exposición Arqueología por el Rio Magdalena del Museo Nacional de Colombia.Además de objetos prehispánicos, la exposición muestra los métodos los procesos y los resultados en la historia de la arqueología colombiana, por lo cual podemos considerarla más que una exposición informativa, una exposición didáctica. Foto: José David García Bonilla.

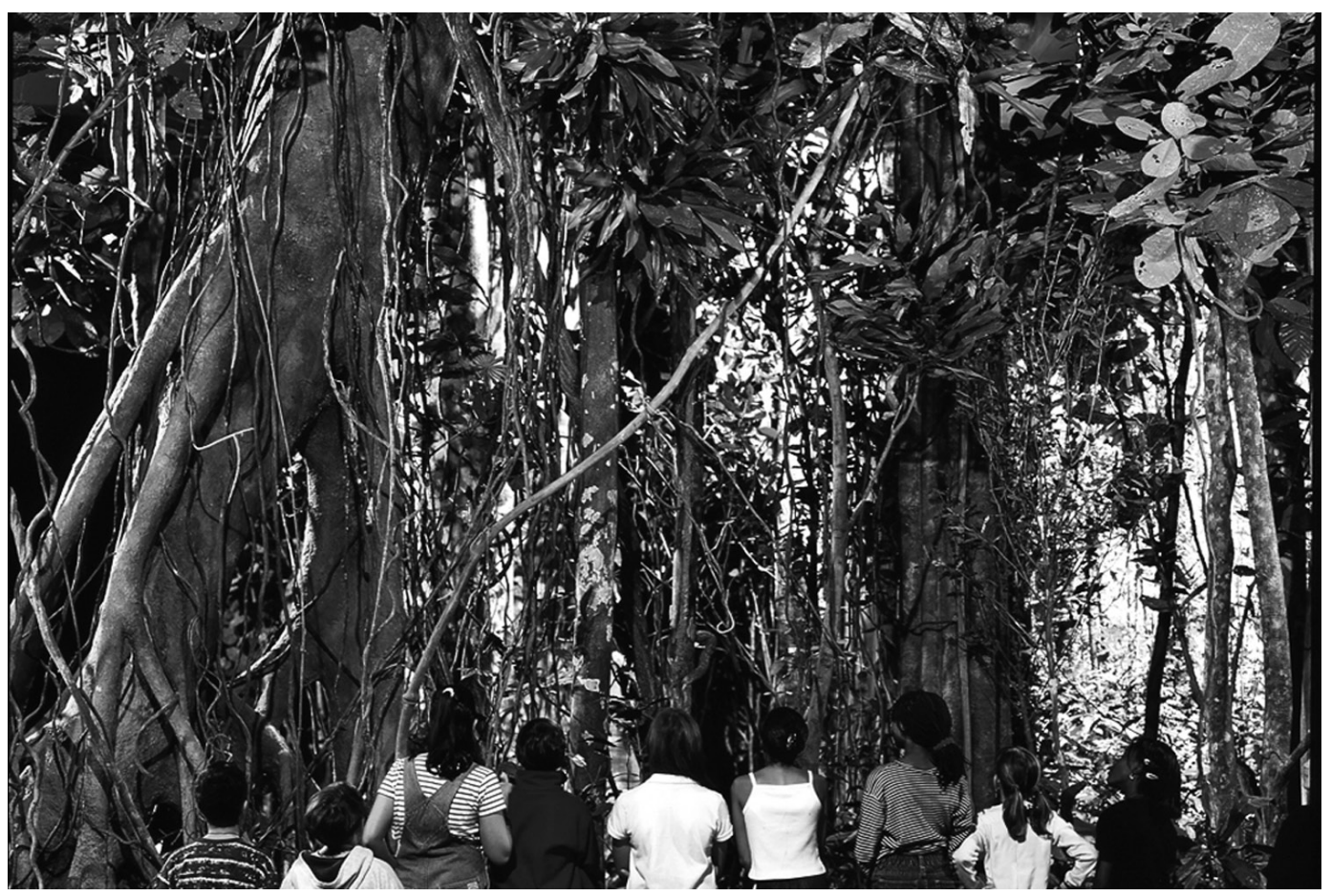

Figura I 10. Exposición evocativa de La selva Dzanga-Sangha en sala de la biodiversidad del Museo de Ciencias Naturales de Nueva York. Se exhiben árboles y vegetación con un realismo impresionante que provocan la sensación de estar en una de las reservas de selva tropical más importantes del mundo. Fuente: American Museum of Natural History web site. 


\section{El contenido de la exposición y su estructuración conceptual}

Para que una exposición logre cumplir su objetivo de comunicación al gran público, ésta debería contar con un discurso de difusión propio, que se determina en función de la intencionalidad. Si bien el discurso especializado se determina como el resultado de la valoración especializada de los objetos, el discurso de difusión debe transformarse a partir de la valoración de los objetos en función de receptores heterogéneos.

En este proceso de manipulación que convierte el discurso especializado, en un discurso de difusión para la exposición se evidencian tres fases. Estas fases, según el Ministerio de Cultura y el Museo Nacional de Colombia, resultan en productos tangibles denominados guiones, estos documentos representan las bases de la exposición y al mismo tiempo se constituyen como instrumentos de trabajo para las oficinas de registro, conservación y museografía (Mincultura, Museo Nacional de Colombia, 2009, pág. 31).

En el guión científico se define de manera concreta la idea general y los temas a tratar en la exposición, basándose en el estudio y en el conocimiento tanto de los objetos de las colecciones, como de lo que se quiere decir con ellas y a quien se quiere decir. Se establece entonces el lineamiento conceptual de la exposición se definen los objetivos, la justificación, el marco teórico, los parámetros temáticos, cronológicos y geográficos entre otros (Mincultura, Museo Nacional de Colombia, 2009, pág. 33).

En el guión curatorial o museológico se seleccionan los objetos y se definen las relaciones entre ellos en función del mensaje. En este punto, se describen los objetos de manera que se relacionen claramente con la idea principal de la exposición considerando los siguientes aspectos: el contenido temático y los subtemas que fundamentan la exposición; la distribución espacial en relación a los temas; los apoyos que proporcionan información sobre la exposición y los objetos; y el material expositivo (Mincultura, Museo Nacional de Colombia, 2009). La relevancia de esta etapa del proceso radica en que es aquí donde se determina la intencionalidad con que se presentan los objetos en la exposición, y en función de esto, se toman las decisiones sobre las relaciones conceptuales que permitan articular la idea de aquello que se quiere decir.

Finalmente, una vez definido el guión curatorial o museológico y en función de las posibilidades materiales de la exposición, éste se transforma en guión museográfico, donde se definen todas las especificaciones relativas a los requerimientos de montaje y su ubicación en la sala.

En las dos primeras fases se concreta el discurso de difusión propio para la exposición, que sirve como pauta para la definición de los elementos relacionados con el montaje de la misma y que completan el total de la puesta en escena, bajo los criterios museográficos pertinentes. 
En la mencionada etapa inicial, la exposición se estructura conceptualmente partiendo de la selección de un tema que es el asunto a tratar y que la sintetiza y engloba. El tema va desarrollándose a lo largo de la misma a través de subtemas que se relacionan entre sí y que van construyendo el total del discurso (como se explica más adelante), contemplando siempre los objetos como aquellos que constituyen la idiosincrasia de la exposición.

Las consideraciones sobre la elección del tema, según García Blanco, indican que éste debe poderse compartir tanto por el equipo productor de la exposición, como por los visitantes; en este sentido resulta conveniente que su elección genere algún tipo de relación significativa tanto para la disciplina científica que construye el discurso especializado de la exposición, como para los visitantes vinculando el tema con algunas de sus experiencias previas, sus modos o intereses de vida (1999). La elección del tema supone entonces considerar lo que podríamos denominar como las intenciones de difusión del museo y por su parte las peculiaridades del público.

Siguiendo a García Blanco, el desarrollo progresivo del tema precisa un desglose del mismo en subtemas o conceptos de nivel inferior y el desarrollo de éstos precisa a su vez un desglose y así sucesivamente, es decir que en la construcción de la estructura conceptual de la exposición, es preciso jerarquizar los conceptos. Pero además de la jerarquía, los conceptos se relacionan entre sí, determinando el carácter discursivo de la exposición; la autora llama a estos dos aspectos macroestructura y supraestructura que definen a su vez los niveles conceptuales de la exposición, que al explicitarse en textos configuran los niveles informativos de la misma (1999, pág. 111). Finalmente este discurso conceptual, debe concebirse construido por objetos.

Ahora bien, los objetos que constituyen la naturaleza de la exposición, no hablan por sí mismos, han sido previamente codificados y seguirán lidiando con nuevas reinterpretaciones en virtud la intención de la exposición. En esta medida, aunque pueden generar múltiples interpretaciones por parte de los visitantes, los objetos dentro del contexto expositivo cumplen una función específica, que representan en relación con el tema o el argumento que la exposición pretende transmitir. Para esto, los objetos se seleccionan y se relacionan entre sí de manera intencionada. Estas relaciones intencionadas son denominadas por García Blanco como claves expositivas.

\section{Atributos y Componentes de la Exposición}

"La exposición se organiza mediante la aplicación de una estructura que cohesiona intencionadamente a los objetos para que signifiquen algo" (García Blanco, pág. 70) es decir el propósito de la exposición, es la razón de ser en función de la cual se re-significan los objetos cargándolos de una verdad temporal. Denominaremos a este atributo como las intenciones de difusión del museo.

La exposición y concretamente el mensaje expositivo, comunica en función de los atributos antes propuestos. Las relaciones entre los atributos tangibles (objetos-espacio-visitantes) deberían estar determinadas por los atributos intangibles (las intenciones de difusión del museo y las peculiaridades del público) propiciando condiciones de retroalimentación, que convierten la exposición en una herramienta que dispone el museo al servicio de la sociedad. 
Los componentes de la exposición se encuentran determinados por las relaciones que se construyen entre sus atributos. Como ya se mencionó, el tema, los objetivos y todo lo relacionado con la fase inicial de la exposición, se define en el guion conceptual. Posteriormente, en el guion curatorial o museológico se definen los parámetros que permitan seleccionar los objetos y las relaciones a crear entre ellos; pero además, en función del visitante no experto, resulta necesario explicitar tanto los objetos en función del mensaje como las relaciones que los asocian, utilizando la información complementaria. La información complementaria hace alusión a lo que se denominaba como "medio secundario" en el modelo de comunicación de Kenz y Wright. Independientemente de su eficacia, la presencia de información complementaria es un inicio de intensión comunicativa y se puede dar en a través de diferentes soportes (García Blanco, 1999).

Los textos escritos son la forma más tradicional y usual de ofrecer información a los visitantes. A diferencia de otros soportes, son autosuficientes, permiten orientar al visitante en el contexto de la exposición, y aún más importante hacer explícito el significado de las piezas, los conceptos y sus relaciones en el contexto expositivo.

Según su contenido se tipifican así (García Blanco, 1999):

Los Textos Orientativos ofrecen una información general, incluyen por ejemplo los textos de señalización y los textos de información sintetizada sobre el contenido de la exposición.

Los Textos Explicativos contextualizan la información dentro de la exposición y se ordenan de acuerdo a su estructura.

Los Textos de Identificación describen los objetos y sus atributos en el contexto expositivos (rótulos y etiquetas).

Otros textos incluyen, entre otros, los folletos o guías, los textos didácticos diseñados en pro del proceso de aprendizaje (García Blanco, 1999, pág. 140) y finalmente aquellos que podrían denominarse como los 'textos decorativos' cuyo objetivo es el de suscitar sensaciones, más que puntualizar un mensaje (la inclusión de fragmentos poéticos o la exploración de los textos como texturas visuales, ilustran esta tipología).

De acuerdo con investigaciones sobre el papel de los textos en las exposiciones (Pérez Santos, 2000), los visitantes sí hacen uso de éstos, leyendo para los demás miembros de un grupo o haciendo comentarios sobre lo leído, este fenómeno es denominado efecto eco (Pérez Santos, 2000, pág. 185). No obstante la lectura de textos ocurre, según los investigadores, cuando se dan las condiciones adecuadas, lo que se refiere "a la capacidad de los soportes para contener información que interese a la visitante plasmada de forma que la percepción del esfuerzo y el tiempo requerido para su lectura sea rentable en términos de adquisición de conocimientos" (Pérez Santos, 2000, pág. 185). La cantidad de trabajos en función de la elaboración de textos eficaces, reafirma la necesidad de incluir textos en las exposiciones, más aun en aquellas que pretenden transmitir un mensaje, que aunque en base de objetos polisémicos, tiene una intención definida. 
Ahora bien, al igual que los textos, los grafismos se constituyen como soportes de información complementaria muy comunes y útiles. A menudo acompañan un texto con el objetivo de contribuir a la visualización de conceptos y la contextualización de ideas, como puede ser el caso de las infografías para el primer caso y las fotografías para el segundo.

Otros medios que son utilizados en las exposiciones son los soportes audiovisuales que incluyen sonoramas, secuencias de diapositivas (presentaciones), videos, pantallas táctiles etc. Las posibilidades tecnológicas actuales han hecho que sean usados con más frecuencia: desde audio guías en diferentes idiomas y sonidos ambientales hasta pantallas táctiles, los medios audiovisuales pueden ser herramientas informativas o de ambientación, siempre en función del mensaje expositivo. La desventaja con éstos radica en los altos costos tanto de inversión inicial como de mantenimiento. Otro factor importante es la utilización de esta herramienta como medio y no como fin, frecuentemente la 'novedad' que supone el uso de un medio audiovisual resulta contraproducente en la aprehensión del mensaje. (García Blanco, 1999, pág. 158).

Los soportes tridimensionales frecuentemente utilizados en Museos de Ciencia y Técnica o de Ciencias Naturales, incluyen modelos, maquetas y dioramas; en algunos casos reproducciones y copias, también hacen parte de las exposiciones. Los soportes tridimensionales se rigen de acuerdo a lo propuesto por el discurso de difusión presentado durante la concepción del proyecto expositivo (guión científico y museológico); posteriormente durante el desarrollo del guion museográfico se proyectan y elaboran este tipo de soportes, junto con los demás soportes tridimensionales restantes que cumplen funciones de ordenamiento, seguridad, exhibición, conservación y montaje, tales como los paneles, las bases, los pódiums y las vitrinas.

Una vez agotadas las etapas del proceso de producción de la exposición, los componentes de ésta al relacionarse crean unidades expositivas (que corresponden a las claves asociativas definidas durante la planeación); éstas a su vez, al relacionarse de forma coherente entre sí, construyen el total de la exposición.

Finalmente, es preciso señalar que la contundencia del mensaje expositivo se encuentra directamente vinculada tanto a la estructura conceptual del mismo, como al tratamiento que se le da a los medios que lo conforman, desde esta perspectiva y en función de la exposición como mediadora, todos sus componentes deberían concebirse desde sus propias condiciones de legibilidad y comprensión; en otras palabras la forma y el contenido. 


\section{Notas}

${ }^{1}$ El presente artículo hace parte del proyecto de grado "Estructuración conceptual de la exposición permanente para el Museo Arqueológico Julio Cesar Cubillos de la Universidad del Valle", presentado en Noviembre de 2012, para optar por el título de Diseñador Industrial.

${ }^{2}$ Para la evolución histórica del concepto he seguido fundamentalmente los primeros capítulos del libro "La difusión cultural en el museo: servicios destinados al gran público" (Valdés Sagüés, 1999).

${ }^{3}$ Para ampliar el tema sobre museología y la museografía, sus orígenes y sus definiciones sugiero revisar "Introducción a la Nueva Museología" (Fernández, 1999) donde se presentan tanto de las definiciones aceptadas por el ICOM, como también los apartes de las reflexiones de los autores que las propusieron.

${ }^{4}$ Algunas de las acepciones aceptadas por el ICOFOM en 2010 y que ejemplifican este nuevo paradigma son las siguientes: « La museología es una ciencia aplicada, la ciencia del museo. Estudia su historia y su rol en la sociedad; las formas específicas de investigación y de conservación física, de presentación, de animación y de difusión; de organización y de funcionamiento; de arquitectura nueva o musealizada; los sitios recibidos o elegidos; la tipología; la deontología». Rivière, 1981 (International Council of Museums ICOM, 2010, pág. 57). "(La museología) es una ciencia que examina la relación específica del hombre con la realidad y consiste en la colección y la conservación consciente y sistemática y en la utilización científica, cultural y educativa de objetos inanimados, materiales, muebles (sobre todo tridimensionales) que documentan el desarrollo de la naturaleza y de la sociedad» Gregórova, 1980 (International Council of Museums ICOM, 2010, pág. 59).

«Actualmente, la museografía se define como la figura práctica o aplicada de la museología...» (International Council of Museums, 2010, pág. 55).

«...la museografía, hecho que acerca el museo a otros métodos de visualización y a otros elementos vinculados a su relación con el público. La aprehensión intelectual y la preservación del patrimonio entran igualmente en juego, convirtiendo al museógrafo en intermediarios entre el conservador, el arquitecto y los públicos.» (International Council of Museums ICOM, 2010, pág. 56).

${ }^{5}$ La definición en ingles no supone ningún cambio terminológico con respecto los términos usados: research y communicates.

${ }^{6}$ Reinwardt Academy es la Facultad de Museología y Patrimonio Cultural de la Escuela de Artes de Ámsterdam.

\section{Tabla de figuras}

Figura. I 1. Jan Brueghel y Peter Paul Rubens El sentido de laVista, 1618. Fuente: Web Gallery of Art http://www.wga.hu/frames-e.html?/html/b/bruegel/ jan_e/2/5sense2.html. (Recuperado: Junio 12 de 2012).

Figura. I 2. François Auguste Biard, "Cuatro horas en el Salón (Cierre del Salón anual de pintura en la Gran Galería del Louvre)” 1847, óleo sobre lienzo. Créditos: Musée du Louvre, Direction des Musées de France, 1999 . Crédits photographiques Arnaudet, Réunion des musées nationaux.

Fuente: Europeana http://www.europeana.eu/portal/record/03919/6D7C7989F3288D34030AC 7A7D0402D0BE20C1E2E.html (recuperado: junio 2012)

Figura. I 3. New Museum, New Museology. SCAD will present Art History Symposium, 2008 . Fuente : DISTRICT | The student voice of SCAD, Savannah College of Art and Design. http:// www.scaddistrict.com/blog/2008/04/03/history-heima-stand-out-among-spring-events/ . (Recuperado: junio 2012).

Figura. I 4. Esquema de comunicación propuesto por Cameron integrando el feed-back. Fuente: Castellanos Pineda, 2008, pag. 25.

Figura. I 5. Modelo de comunicación aplicado a los Museos de Ciencias según Knez y Wright. 
Fuente: Hooper-Greenhill, 1998, pág. 37

Figura. I 6. Modelo de comunicación de Shannon y Weaver. Fuente: Fuente: Hooper-Greenhill, 1998, pág. 31.

Figura. I 7. Modelo de Shannon y Weaver aplicado a los Museos de Ciencias.

Fuente: Castellanos Pineda, 2008, pág.30.

Figura. I 8. Exposición de los 100 años del nacimiento de Jackson Pollock en el MoMa. Abril 22 de 2012.

Foto: Associated Press. Fans pay tribute to Jackson Pollock 100 years after birth 4/22/2012

http: / /www.toledoblade.com/Art/2012/04/22/Fans-pay-tribute-to-Jackson-Pollock-100-years-afterbirth.html (recuperado: Julio 11 2012).

Figura. I 9. Exposición Arqueología por el Rio Magdalena del Museo Nacional de Colombia. Foto: José David García Bonilla. Mayo 27 de2012.

Figura. I 10. Exposición evocativa de La selva Dzanga-Sangha en sala de la biodiversidad del Museo de Ciencias Naturales de Nueva York.

Foto: American Museum of Natural History web site http://www.amnh.org/exhibitions/permanentexhibitions/biodiversity-and-environmental-halls/hall-of-biodiversity/the-dzanga-sangha-rain-forest (recuperado junio de 2012)

\section{Referencias}

Belcher, M. (1997). Organizacion y diseño de exposiciones. Su relación con el museo. (F. Alvarez ,Trad.) Gijón, Asturias, España:TREA,S.L.

Castellanos Pineda, P. (2008). Los Museos de ciencia y el consumo cultural: Una mirada desde la comunicación. Barcelona: Editorial Uoc, S.L.

Constitucion Nacional. (1991). Titulo II. Cap 2. Art.70. Recuperado el 14 de Junio de 2011, de Juriscol: http: / / juriscol.banrep.gov.co/contenidos.dll?f=templates $\$ \mathrm{fn}=$ default.htm $\$ 3.0$

De Carli, G. (2004). Un Museo Sostenible. Museo y Comunidad en la Preservación activa de su Patrimonio. (Unesco, Ed.) Recuperado el 22 de Septiembre de 2011, de Oficina de la Unesco para America Central ISBN:9968-9656-0-X: http:/ / www.nuevamuseologia.com.ar/index.php?option= ${ }_{\text {com }}$ content\&view $=$ article\&id=247:un-museo-sostenible\&catid=39:libros\&Itemid=399

Fernández, L. A. (1999). Introducción a la nueva museología. Madrid, España: Alianza Editorial, S.A.

García Blanco, Á. (1999). La exposición, un medio de comunicación. Madrid, España: Ediciones Akal, S.A.

Hernández Hernández, F. (1 de Enero de 1992). Evolución del concepto de museo. (U. Universidad Complutense de Madrid Servicio de Publicaciones, Editor) Recuperado el 26 de Junio de 2009, de Revista General de Información y Documentación; Vol 2, No 1 (1992): http://revistas.ucm.es/index.php/RGID/article/ view/RGID9292120085A

Herreman, Y. (2007). Presentaciones,obras expuestas y exposiciones. En UNESCO e ICOM, Cómo administrar un Museo: Manual Practico. (págs. 91-103). Paris, Francia: UNESCO.

Hooper-Greenhill, E. (1999). The Educational Role of the Museum (Segunda ed.). Pastow, Cornwall, Great Britain: TJ International Ltd.

International Council of Museums. (2010). Conceptos Claves de Museología. (ICOM) Recuperado el 15 de Julio de 2011, de Comité internacional del ICOM para la museología - ICOFOM: http://icom. museum/fileadmin/user_upload/pdf/Key_Concepts_of_Museology/Museologie_Espagnol_BD.pdf

Ley 1450 de 2011. (16 de Junio de 2011). Plan Nacional de Desarrollo 2010-2014. Recuperado el 30 de Agosto de 2012, de Juriscol: http:/ / juriscol.banrep.gov.co:8080/ contenidos.dll?f=templates $\$$ fn $=$ default htm \$3.0\&vid= default

Ley 397 de 1997. (1997). Ley General de Cultura. Recuperado el 14 de Junio de 2011, de JURISCOL: 
http: / /juriscol.banrep.gov.co:8080/contenidos.dll?f=templates $\$ \mathrm{fn}=$ default.htm $\$ 3.0 \&$ vid $=$ default Marín Espinoza, E. (2004). Museos Arqueologicos del Valle del Cauca: pasado, memoria y olvido.(Tesis de pregrado). Popayan: Universidad del Cauca.

Mesa Redonda de Santiago de Chile . (31 de Mayo de 1972). Ibermuseos. Recuperado el 1 de Diciembre de 2011, de Ibermuseos.org: http://www.ibermuseus.org/wp-content/uploads/2011/04/copy_ of_declaracao-da-mesa-redonda-de-santiago-do-chile-1972.pdf

Mincultura, Museo Nacional de Colombia. (2009). Curaduría en un museo. Nociones básicas. Bogotá: Editora Géminis Ltda.

Ministerio Nacional de Cultura. (2001). Memorias de los Coloquios Nacionales: La Arqueologia, La Etnografia, La Historia y El Arte en el Museo. Bogotá: Ministerio Nacional de Cultura. Museo Nacional de Colombia.

Nogales Basarrate, T. (2004). La investigación en los museos: una actividad irrenunciable. Recuperado el 15 de Septiembre de 2011, de Revista Museo.es. Ministerio de Cultura: Subdirección General de Museos Estatales.: http: / / dialnet.unirioja.es/servlet/revista?codigo $=5877$

Núñez, A. (2007). El museo como espacio de mediación: el lenguaje de la exposición museal. Recuperado el 7 de Mayo de 2010, de Red de Revistas Científicas de América Latina y el Caribe, España y Portugal.: http://redalyc.uaemex.mex

Nuñez, A., \& Marin, E. (2007). Proyecto de elaboracion del nuevo guión museográfico Museo Arqueologico La Merced. Fondo de Promocion de la Cultura.

Olmos, R. (2002). Los investigadores y el Museo: una lectura entre otras muchas. Recuperado el 15 de Septiembre de 2011, de Revista Museo.No.6-2002: I-II Asociación Profesional de Museólogos de España.: http://www.apme.es/revista/museo06-07_209.pdf

Pérez Santos, E. (2000). Estudio de visitantes en Museos: metodologia y aplicacion. Gijón, Asturias, España: Edisiones Trea,S.L.

UNESCO. (s.f.). Ibermuseos. Recuperado el 26 de Enero de 2012, de http:/ /www.ibermuseus.org/wpcontent/uploads/2011/04/copy_of_declaracao-da-mesa-redonda-de-santiago-do-chile-1972.pdf

Valdés Sagüés, M. d. (1999). La difusión cultural en el museo: servicios destinados al gran público. Gijón, España: Ediciones Trea.

Weil, S. E. (1992). Rethinking the museum. An emerging new paradigm. En G. Anderson, \& G. Anderson (Ed.), Reinventing the Museum.Historical and Contemporary Perspectives on the Paradigm Shift (págs. 74-78). Walnut Creek, California, EE UU: AltaMira Press.

Recibido: octubre 30 / Aprobado: noviembre 28 de 2013 